\title{
Gender Differences in Using Language
}

\author{
Xiufang Xia \\ Qingdao University of Science and Technology, China
}

\begin{abstract}
The differences between men and women in using language have been studied long time before. This paper mainly discussed the differences from the aspects of pronunciation, intonation, vocabulary, syntax, manners, attitudes, and non-verbal differences in using language between men and women. Besides the differences in various aspects, the paper tries to record the changes of these differences. On the basis of these differences and changes, the paper also tries to make some explanation to these differences and changes.
\end{abstract}

Index Terms - differences, language, gender

\section{INTRODUCTION}

Over the past thirty years, and as a result of the women's movement, gender issues have become connected with the issue of language. Gender studies and language studies are both interdisciplinary academic field. The study of language began from thousands of years ago, while the study of gender is quite short. "Gender studies have developed differently, achieving the greatest influence in North America; the 'era of feminism' that began in the late 1960s and affected academic and public life as well as 'high' and popular culture has been instrumental in shaping the historical and scholarly context of its generation. Feminist work has entered and had an impact upon almost every academic discipline." (Flotow, 2004. p.1)

The study of gender is important to the study of language, and the first step to study gender is to explore the difference between men and women. It is quite clear that men and women have a lot of differences in many fields. Generally speaking, females have more fat and less muscle physically; women are not as strong as men and they mature more rapidly and usually have a longer life span. Females and males often show different advantages and skills in doing their work. Why are the two genders different in so many ways? Besides some physical reasons, we are aware that social factors may account for some of the differences. Such as, women may live longer than men because of the different roles they play in society and the different jobs they tend to do. Men usually have to undertake more pressure than women in life. The differences in job skills may be explained in great part through differences in the ways by which they are raised. When talking about language, we can't help asking if men and women who speak a particular language use it in different ways? If they do, then we may ask in what ways they are different. Do the differences change through time? This paper attempts to explore these differences, and examine the changes through time, and gives these differences and changes some possible explanations.

\section{Male-Female Difference In Their Using Language}

Language reflects, records, and transmits social differences, so we should not be surprised to find reflections of gender differences in language, for most societies differentiate between men and women in various marked ways. The paper will examine the differences from the following aspects.

\section{A. Differences in Pronunciation}

Phonological differences between the speech of men and women have been noted in a variety of languages. Usually women's pronunciation is better than men's, such as the pronunciation of "-ing". Shuy (1969) made a study in this field, and he found that $62.2 \%$ of men pronounced "-ing" in a wrong way, but only $28.9 \%$ of women didn't pronounce right. This can also be shown in the learning of the second language. Usually female students have better pronunciation than male students, and that can explain the reason why more girls choose to learn language as their major than boys. Generally speaking, girls exhibit a better ability in language.

\section{B. Differences in Intonation}

Women often like to speak in a high-pitch voice because of physiological reason, but scientists point out that this also associates with women's "timidity" and "emotional instability". Besides the high-pitch voice, women prefer to use reverse accent as well.

Example: Husband: When will dinner be ready?

Wife: Around six o'clock..

The wife is the only one who knows the answer, but she answers her husband with a high rise tone, which has the meaning "will that do". This kind of intonation suggests women's gentility and docility. The husband will surely feel his wife's respect. Lakoff (1975) says that women usually answer a question with rising intonation pattern rather than falling intonation. In this way, they can show their gentleness, and sometimes this intonation shows a lack of confidence. 
As a contrary, men like to use falling intonation to show that they are quite sure of what they are saying. Falling intonation also shows men's confidence and sometimes power.

\section{Differences in Vocabulary}

We can notice that men and women tend to choose different words to show their feelings. For example, when a woman is frightened, she usually shouts out, "I am frightened to death"! If you hear a man says this, you'll think he is a coward and womanish.

The differences in vocabulary can be shown in the following five aspects:

a. Color Words

There is special feminine vocabulary in English that men may not, dare not or will not use. Women are good at using color words that were borrowed from French to describe things, such as mauve, lavender aquamarine, azure and magenta, etc, but most men do not use them.

b. Adjectives

In our everyday life, we can notice that women like to use many adjective, such as adorable, charming, lovely, fantastic, heavenly, but men seldom use them. When a woman leaves a restaurant, she will say "It's a gorgeous meal". If a man wants to express the same idea, he may only say, "It's a good meal." Using more adjectives to describe things and their feelings can show that women are more sensitive to the environment and more likely to express their emotions with words, which makes women's language more interesting than men's sometimes.

c. Adverbs

There are also differences in the use of adverbs between men and women. Women tend to use such adverbs like awfully, pretty, terribly, vastly, quite, so; men like to use very, utterly, really. In 1992, Jespersen found that women use more so than men do, such as, "It was so interesting" is often uttered by a woman.

d. Swear words and Expletives

Maybe because women are gentle and docile, they usually avoid using swear words and dirty words. They believe that these kinds of words will not only make others uncomfortable and give an impression of "no civilization", but also destroy the relationship between her and others. Women always pay more attention to the grace of themselves and their use of language. We rarely hear that women utter such words like "damn, fuck you, hell," instead they use "oh, dear, my god" to express their feelings. Let us examine the following examples:

Woman: Dear me! Do you always get up so late? It's one o'clock!

Man: Shit! The train is late again!

We can often here similar ways of expressing shock in every day life. Men tend to use more swear words than men. Women pay more attention to their manners and politeness of using language.

e. Diminutives

Women like to use words that have the meaning of "small", such as bookie, hanky, panties. They also like to use words that show affections, such as dearie, sweetie. If a man often uses these words, people will think that he may have psychological problem or he is not manly.

Furthermore, women like to use words that show politeness, such as please, thanks, and they use more euphemism, but "slang" is considered to be men's preference.

From the study we can see that men and women have their own vocabulary choices in achieving emphatic effects. Though in the area of vocabulary, many of the studies have focused on English, we can not deny that sex differences in word choice exist in various other languages. People need to learn to make these distinctions in their childhood.

f. Pronouns

Women prefer to use first person plural pronouns when they suggest something, even when she suggests the other person, while men tend to use first person singular pronoun, and when he is suggesting the other person, he will directly use the second person pronoun.

Example: Women: We need to be in a hurry.

Men: You need to be quick.

\section{Difference in Syntax}

Though there are no specific rules that govern different gender to use different grammar, we can observe these differences in almost every language.

a. Modulation

When a woman talks, she often takes what others think into consideration. She usually leaves a decision open rather than imposes her own ideas or claims on others. We often hear a woman say "well, you know..., I think..., I suppose....kind of, maybe I am wrong but..., etc.

When they want to get help from others, men and women express in different ways as the following:

Women: I was wondering if you can help me.

Men: please give me a hand.

From the above example we can see men tend to ask something directly, while women tend to be more polite.

b. Interrogative sentences

Women use more interrogative sentences than men do. Women look interrogative sentences as a strategy of 
continuing a good conversation. Lakoff (1975) pointed out that compared with men, women are more likely to use an interrogative sentence to express their idea, and they like to use tag questions, because tag questions can make the tone less tense. Fishman (1980) collected many couples' conversation tapes, and he found that women used three times of tag questions as men did. In these conversations, they were 370 interrogative sentences, among which women used 263 , almost two and a half of times of men did. This point is similar to the difference in intonation between men and women. Just as Lakoff (1975) said that women might answer a question with rising tone, while men like to use falling tone to make a firm statement. According to Lakoff (1975), women tent to do this because they are less sure about themselves and their opinions than men. The different use of language also shows that women are more likely to be short of confidence. From another aspect, we can say that women are more polite and considerate than men.

c. Imperative sentences

A study observed a group of boys and girls on one street in Philadelphia, and the study found that the imperative sentences that the boys and girls use were different. The boys used a lot of imperative sentences but the girls used more "let's patterns".

Example: Boy: Give me an apple!

Girl: Would you give me an apple?

Boy: It's time to go.

Girl: Let's go.

The research also found that girls prefer to use sentences with modal verbs, such as can, could, may. But they seldom use imperative sentences to give orders. To reduce the imperative tone, they use more adverbs like maybe, perhaps, probably.

d. Correctness of grammar

Women pay more attention to the correctness of syntax. While expressing her thoughts, she would make her utterance clear by using precise grammar.

Example: Woman: We are going to $g$ to the park today.

Men: We are gonna to the park today.

\section{E. Differences in Their Attitudes toward Language}

Women pay more attention to using standard language than men do, so they are stricter with the rules of the use of language.

Example: Man: Are you comin'?

Woman: Are you coming?

Women tend to use the standard form. This point is emphasized in the difference of pronunciation.

In Detroit, people like to use multiple negations, such as: I do not want none. Research found that men use much more of this kind of substandard form than women. This can be seen from movie "Forrest Gump. Influenced by the southern accent, Forrest often uses double negative to show negative meaning.

\section{F. Non-verbal Differences: Differences in Manners}

We have mentioned that women usually show politeness in their conversation, such as he use of "would you, please, etc." Besides this, women also show that they are reserved when they talk. The following table is based on the research of Zimmerman and West on the interruptions men and women made in a conversation.

\begin{tabular}{|l|l|l|l|}
\hline & male & female & total \\
\hline interruptions & 46 & 2 & 48 \\
\hline
\end{tabular}

We can see that men continued interrupting other's talk, instead women are more patient. Even though they want to talk, they will wait until others stop their talking. Generally speaking, in a conversation involving both sexes, women often play the role of patient listeners. They do not interrupt others often, but encourage others to talk. However, men are eager to be heard, which pushes them to catch as many opportunities as possible. Men do not like to be silent. This makes them appear to be more active than women. In other words, in a conversation involving both sexes, women tend to be silent.

\section{G. $\quad$ Differences in Choosing Topics}

In social interaction, men and women have different interests in choosing their topics. When men are talking, they are more likely to choose the topics of politics, economy, stocks, sports, current news. While women have more interest in talking family affairs, such as the education of children, clothes, cooking, fashion, etc. Women's talk is associated with the home and domestic activities, while men's is associated with the outside world and economic activities. Thus, while there is a popular prejudice that women talk more than men, empirical studies of a number of social situations such as committee meetings and internet discussion groups have shown the opposite to be true. Women may talk more in informal occasions than men, but they surely play the second role in the formal occasions and tend to speak less than men. Sociolinguists studied women's silence in public situations as well as the linguistic work they do in their partnerships (Spender, 1980). Besides these differences, other sex-linked differences exist, such as women and men may have different paralinguistic system and move and gesture differently. 


\section{SOME POSSIBLE EXPLANATION}

It's not enough to find these differences. The more important thinking is to find what cause these differences. In a recent set of studies about the physical differences between the two genders, phonological processing in males was shown to be located in the left of the brain and in females to involve both left and right parts of the brain. No difference in efficiency was shown, nor is there any evidence so far that any neurophysiologic difference accounts for differences between the two groups in using language, so we can get the conclusion that the causes are social rather than physical. Since biological sexual differences cannot explain the differences in men's and women's societal roles and opportunities, scholars developed and employed other tools and analytical categories in order to understand these discrepancies. "Beauvoir suggests that a baby born with female reproductive organs does not simply grow up to be a woman. She has to turn herself into a woman, or more correctly, she is turned into a woman by society she grows up in and in response to the expectations an conditioning, and differs according to the dominant influences she is subject to in the subculture, subculture, ethnic group, religious sect, in which she grows up." (Flotow, 2004. p.5)We can explore this issue from three aspects.

\section{A. Different Psychology}

It's an accepted idea that women are more careful, sensitive and considerate than men. Before a woman talks, she usually thinks the effect her words will cause, so she often appears to be more polite. On the contrary, men appear to be rash, and they just say what they want to say and seldom care what others think, so men's speech is usually blunt and solid.

\section{B. Different Social Status}

Of the social causes of gender differences in speech style, one of the most critical is level of education. In all studies, it has been shown that the greater the differences between educational opportunities for boys and girls, the greater the differences between male and female speech. Usually, in many parts of the world, males are expected to spend longer time in schools. When offered an equal educational opportunity, there seems to be a tendency for women to be more sensitive than men to the status norms of the language.

Though many linguists have noticed the differences between the use of men and women, it was not until the 70s that some linguists tried to find the social root of these differences. Men and women differ in the kinds of language they use and how they use it because men and women often fill different roles in society. We may expect that the more distinct the roles are, the greater the differences. Almost in every country, most of the important positions in governments are held by men. Men can almost dominate everything, including women. Most scholars notice that women's tone is not that self-confident as men's, and they point out that this is because they have little power or no power at all in the society. Women's social status makes them appear to be submissive to men. Women are often named, titled and addressed differently from men, such as women are more likely than men to be addressed by their first names. Women are inferior to men in this society, so they appear to be non-assertive when they talk. They tend to discuss, share and seek reassurance. On the contrary, men tend to look for solutions, give advice and even lecture to their audience. The term gender was often understood to be the basis of women's subordination in public and private life. Women are supposed to be the second class in the household as well as in the workplace, everywhere from the pink-collar ghettos of the corporations, via images of women in the media to government or educational agencies establishing policies affecting women. Activities criticizing the gendered aspects of everyday life kept the issue in the public eye; interest and support were galvanized by media events such as the disruption of the Miss America Pageant in 1968, where the trappings of stereotypical femininity-dish-cloths, steno pads, girdles and bras-were thrown into a 'Freedom Trash Can' (Morgan, 1968, p. 62-67).

The use of genetic masculine, such as Everyone must increase his awareness of environment protection, reinforces the secondary status of women in many social groups. This kind of usage does not jus reflect and record current prejudices, but they are easily transmitted, reinforcing the lower power and prestige ascribed to women in a society. With the growth of social awareness in many parts of the world over the past decades, there have been many attempts to overcome this prejudicial use of language. For instance, people use the word chairperson instead of chairman more frequently nowadays. Many publishers and journals now adhere to guidelines to avoid gender stereotyping and gender prejudiced language use.

Women are very conscious about their status, and they long for a better position in society, so they try to improve themselves, including using standard language. Women are more conscious of using languages which associate with their "betters" in society, that is, those they regard as being socially superior. They therefore direct speech towards the models these provide, even to the extent in some cases of hypercorrection. On the other hand, men are powerful, including the lower-class men. They are less influenced by others.

\section{Different Cultural Background}

For whatever languages, there are peoples' unique life styles and modes of thinking behind them. It's these life styles and modes of thinking that make the rules of languages, so language is also a kind of cultural phenomenon. Lakoff (1975) believes that the distinction between men's and women's language is a symptom of a problem in our culture, and not primarily the problem itself. For example, in North America, men and women come from different sociolinguistic 
subculture. They have learned to do different things with language. To cite another example, the Yana language of California contains special forms for use in speech either by or to men. We can see form above that cultural background influences men's and women's behavior, including language.

\section{Changes through Time}

“The women's movement of the late 1960s and early 1970s tried to show how women's difference from men was in many ways due to the artificial behavioral stereotypes that come with gender conditioning. Since these stereotypes were artificial, they could be minimized" (Flotow, 2004, p.8). Language has a great connection with society, so if change in society occurs, change in language too. With the development of productive forces and civilization, the strict rules that the society prescribes for men and women are changing. Many territories not only belong to men any more. Women are not the on-lookers; instead they begin to take a more assertive role in what goes on. For example, in a study of how the inhabitants of Obserwart are shifting from a pattern of stable bilingualism in German and Hungarian to the use of only German, the young girls are especially in the forefront of the language change there. Women are eager to change their social statues, and they want to be equal with men in every field. Nowadays, more and more women walk out their homes; and even more and more of them are in the high positions in the governments. Their ability tells people that the jobs can be also done well by women. With the changes in their social status, women become more confident and assertive than before. Why should they use more euphemisms? Why should they use reverse accent even they are sure about what they say? Why should they keep silent when men are talking? They have the confidence to say what they want to say directly now, they also have the courage to interrupt men's talk. They are brave enough to lecture to men, not only being lectured by men. When we learn Japanese, we notice that in modern Japanese, the rules are not that strict as they were before. This is the result of modern civilization, and this is also the result women strive for.

People's linguistic behavior is not only connected with social status, but also connected with their profession, education, etc. In modern society, more and more people receive high education, so we can see that more and more men begin to behave themselves when they talk. Usually, they seldom break into other's conversation abruptly. Instead they are patient enough to wait others to finish their talks. They use less rigid impressive sentences. We can hardly hear them using swear words or taboos. They become polite and gentlemen-like. The interesting thing is that they also begin to use tag questions.

\section{CONCLUSION}

Gender as an analytical category continues to motivate researchers in many areas. This paper has seen the differences between the use of language of men and women from some aspects, and we can notice that there are many differences in using language between the two genders, and also there are some changes through time. We believe that with the development of society, there will be fewer differences in the usage of language. Language, as a tool of human communication, will be improving day by day, and this needs the effort of both men and women. "The establishment of women's studies' initiatives developed from this sense of women's commonality as well as from the realization that women were excluded from large parts of public and academic life." (Flotow, 2004. p.6). With more participation into the social life, business, academic field and so on, there will be other changes in the future. The changes in the language can show the improvement in women's social status.

\section{REFERENCES}

[1] Fishman, M. (1980). An Introduction to Sociolinguistics. Malden: Blackwell publishing.

[2] Flotow, Luise von. (2004). Translation and Gender. Shanghai: Shanghai Foreign Language Education Press.

[3] Lakoff, R. (1975). Language and Women's Place. New York: Harper\&Row Publishers, Inc.

[4] Morgan, Robin. (1968). Going Too Far. The Personal Chronicle of a Feminist. New York: Random House.

[5] Shuy, D. (1969). A Cultural Approach to Male-Female Miscommunication. London: Routledge.

[6] Spender, Dale. (1980). Man Made Language. New York \& London: Routledge \& Kegan Paul.

Xiufang Xia was born in Weifang, China in 1975. She received her MA degree in linguistics from Ocean University of China in 2002.

She is currently a lecturer in Qingdao University of Science and Technology, China. Her research interests include functional linguistics and translation theory. 